\title{
Inequality, the crisis, and stagnation
}

\author{
Till van Treeck \\ University of Duisburg-Essen, Germany
}

This article focuses on the macroeconomic implications of inequality by identifying four themes on which there seems to be growing consensus among many economists, especially in the various heterodox traditions, but also increasingly in the mainstream of the economics profession. The first theme on which there is growing consensus is the notion that the rise in inequality has contributed in an important way to the unsustainable rise in household debt in the United States and ultimately the financial and economic crisis starting in 2007. Second, there is the by-now widely held view that rising inequality at the international level has contributed to the so-called global imbalances in terms of national current-account positions. Third, there has recently been a shift in the focus of attention from merely looking at income inequality to analysing the longer-term implications of income inequality for wealth inequality. Fourth, the argument has been made that a high level of inequality can, generally speaking, be a cause of low economic growth, or even secular stagnation. The article gives a broad and non-technical overview on how these issues can be seen to be linked.

Keywords: income distribution, wealth distribution financial crisis, household debt, current-account imbalances, stagnation

JEL codes: E21, F32, F41

\section{INTRODUCTION}

The inequality of income and wealth is one of the defining issues of our time, in terms of both its social and its macroeconomic implications. In this paper, I focus on the macroeconomic implications of inequality. In particular, it is possible to identify four themes on which there seems to be growing consensus among many economists, especially in the various heterodox traditions, but also increasingly in the mainstream of the economics profession.

The first theme on which there is growing consensus is the notion that the rise in inequality has contributed in an important way to the unsustainable rise in household debt in the United States and ultimately to the financial and economic crisis starting in 2007 (see, for example, Palley 1994; Dutt 2006; Frank 2007; Fitoussi/Stiglitz 2009; Kumhof/Rancière 2010; Rajan 2010; Mian/Sufi 2014; Cynamon/Fazzari 2015a; 2015b).

Second, there is the by-now widely held view that rising inequality at the international level has contributed to the so-called global imbalances in terms of national current-account positions (see, for example, Hein/Truger 2012; Kumhof et al. 2012; van Treeck/Sturn 2012; Behringer/van Treeck 2013; Belabed et al. 2013; Stockhammer 2013).

Third, there has recently been a shift in the focus of attention from merely looking at income inequality to analysing the longer-term implications of income inequality for wealth inequality (for example, Piketty 2014; Saez/Zucman 2014). And fourth, the argument has been made that a high level of inequality can, generally speaking, be a cause of low economic growth, or even secular stagnation (for example, Dutt 2006; Palley 2012; Cingano 2014; Ostry et al. 2014; Ostry 2015). 
While it would be beyond the scope of this paper to go into the details of each of these important issues, I will try to give a broad and non-technical overview on how these issues can be seen to be linked. ${ }^{1}$ Section 2 discusses the link between income inequality and the United States (US) household debt crisis. Section 3 discusses the link between changes in income distribution and the current-account surplus of Germany. Section 4 looks at the relation between income distribution and current-account imbalances for a panel of 20 industrialized countries. Section 5 then goes on to discuss the implications of the empirical findings for the evolution of wealth inequality. Section 6 concludes by arguing that inequality may indeed turn out to be one of the main causes of secular demand stagnation.

\section{THE INEQUALITY-CRISIS NEXUS IN THE UNITED STATES}

Figure 1 shows the spectacular rise in the share of total pre-tax household income going to the top of income distribution in the United States, which started in the early 1980s. Figure 2 shows the equally spectacular decrease in the private household saving rate, also starting in the early 1980 s, to near 0 per cent just before the crisis. It also shows that households' debt-to-income ratio increased very strongly in the United States over the same period.

These macroeconomic trends are intriguing, not least from a traditional Keynesian point of view. In fact, simple Keynesian models would predict that higher income inequality leads to a higher aggregate saving rate, because rich households have a lower marginal propensity to spend than poor households. On the other hand, models with upward-looking status

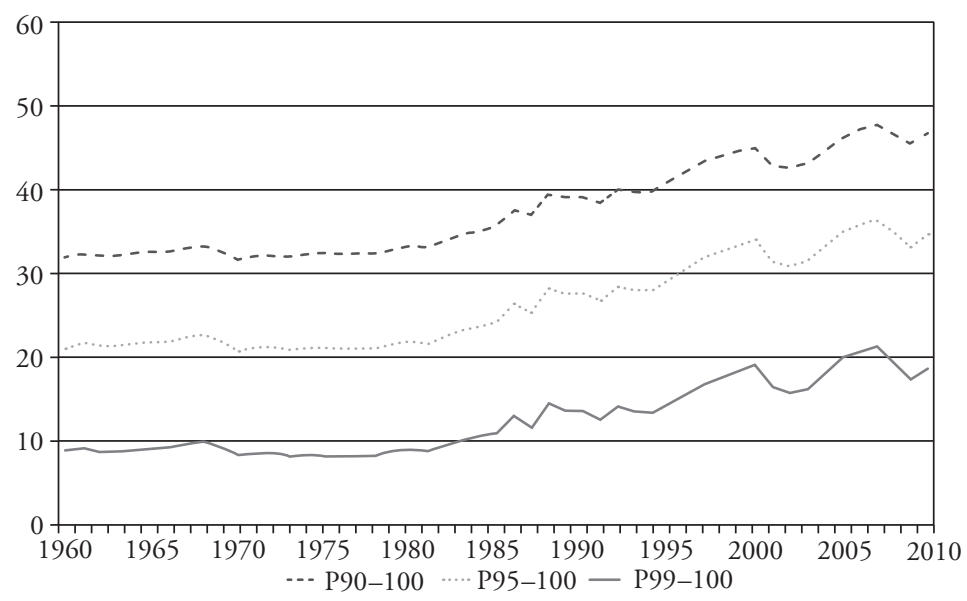

Source: http://eml.berkeley.edu/ -saez/.

Figure 1 Top 1 per cent, 5 per cent and 10 per cent of household incomes as a percentage of total pre-tax household income (including capital gains), United States, 1960-2010

1. This paper draws on van Treeck/Sturn (2012) and Behringer et al. (2013; 2014). 


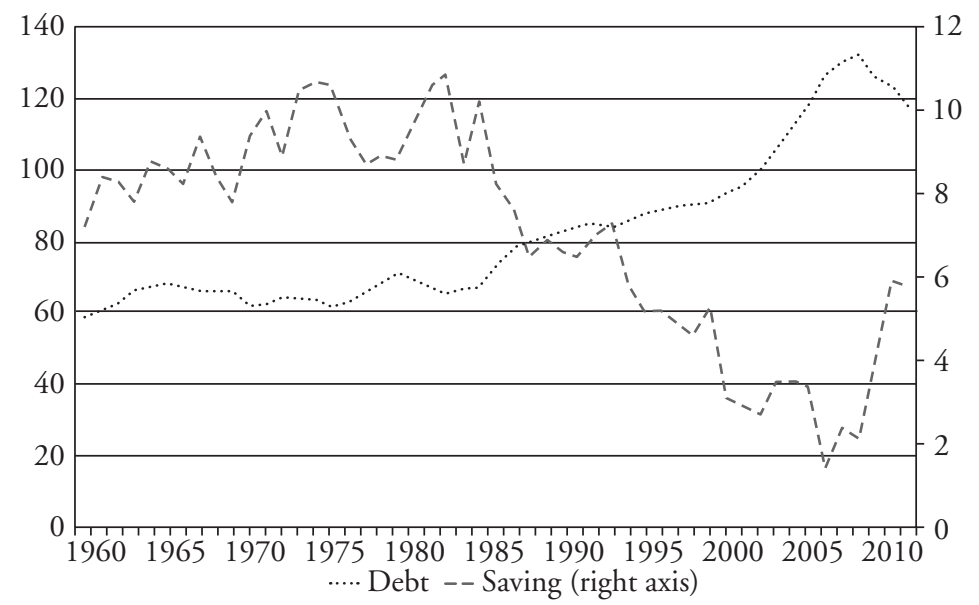

Source: Bureau of Economic Analysis, Federal Reserve.

Figure 2 Debt and saving as a percentage of household disposable income, United States, $1960-2010$

comparisons, like some variants of the relative income hypothesis, predict a negative link between inequality and the aggregate saving rate (Frank 2005). According to this view, households just below the top of the distribution in the United States, which could be called 'upper middle class', have reduced their saving in order to try to keep up with the spending patterns of households at the top. This, in turn, may also have increased the pressure on the lower-middle and lower classes to increase spending relative to their incomes. Ultimately, therefore, the rising standard of living at the top of the distribution has affected the consumption norms of the entire income distribution ('expenditure cascades'; see Frank et al. 2014).

It is important to emphasize that this explanation of the fall in the saving rate is not primarily about the saving behaviour of poor households. By definition, poor households receive only a small share of total incomes, hence the effect of the saving behaviour of poor households on the aggregate saving rate is rather limited. By contrast, the relative income hypothesis in the US context highlights the difficulties faced by the middle and upper-middle class in providing for what they perceive as basic needs in the face of rising inequality at the top of the distribution. Typical middle-class needs include the aspiration to send their children to relatively good schools or universities, to live in relatively decent neighbourhoods, or to achieve a relatively high standard of health care.

All of these goods can be qualified as positional goods: what matters for the career prospects of one's children, for example, is the relative quality of their education rather than its absolute quality. Clearly, not everybody can attend better than average schools, and even though today's relatively bad schools may be better than in the past, career prospects strongly depend on the quality of one's education relative to others of their generation. Similarly, social status depends not so much on the absolute size or price of one's home, but rather on its relative price. Again, not everyone can live in a more expensive home or neighbourhood than the average person would aspire to. But the relative decency 
of a neighbourhood also determines the relative quality of the infrastructure and social networks that are important for households to strive economically.

Now, when people just above a given family in the income distribution scale begin to spend much more money on education - simply because their incomes increase - but at the same time that given family's own income is stagnant, then that family either has to accept that the relative quality of their children's education decreases, or they can reduce their saving and go into debt. And this seems to be what many US middle-class households have done; that is, they have traded-off their retirement savings for the purchasing of positional goods such as education, housing or health care. Clearly, and importantly in this context, the institutional environment in the United States, where most of these basic needs have to be paid for privately, puts enormous pressure on households to save less and go into debt, as their relative incomes decrease. Moreover, given the uncertainties surrounding future income prospects and the dependence of future income on the current consumption of positional goods, it is not clear whether households' decisions to 'live beyond their means' can be qualified as 'irrational', at least from the perspective of any given individual household.

Evidence in favour of the above explanation of the decrease in the US household saving rate can be provided based on micro data. As shown by Saez/Zucman (2014), it was the bottom 99 per cent of the wealth distribution who strongly reduced their saving rates starting in the early 1980s, whereas the saving rate of the top 1 per cent remained roughly stable. Meanwhile, the rise in the debt-to-net worth and the debt-to-income ratios took place within the bottom 95 per cent of the distribution, and not at all at the top (Kumhof/Rancière 2010; Cynamon/Fazzari 2015a; 2015b).

Finally, it may be important to emphasize the fact that the functional distribution of income (the distribution of the national income between wages and profits, or between household and corporate income) has been much more stable in the United States since the 1980s, compared to the personal distribution of income (the distribution of income between households). As Figure 3 shows, even though the wage share has

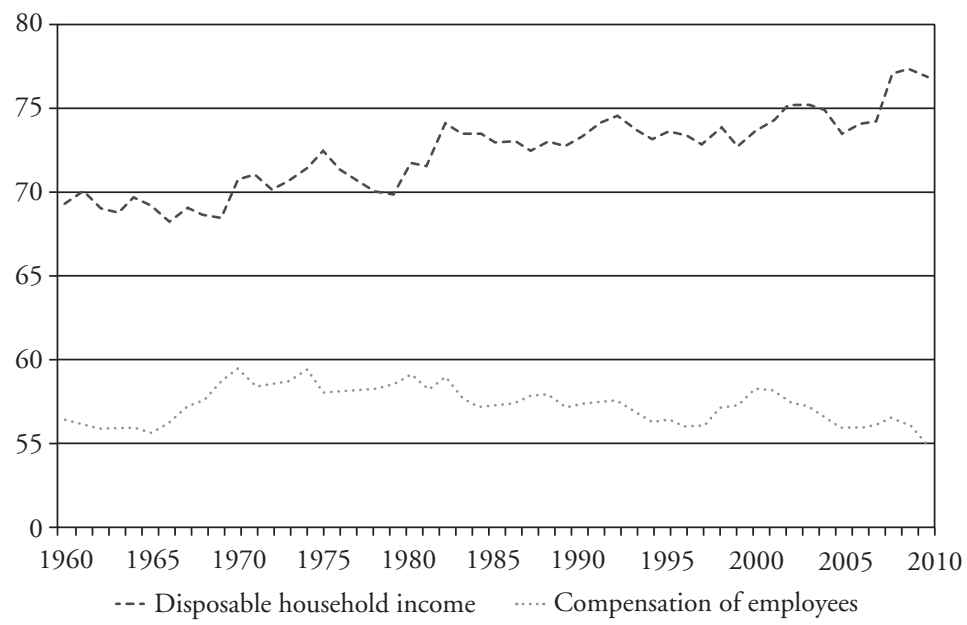

Source: Bureau of Economic Analysis, Federal Reserve.

Figure 3 Disposable household income and compensation of employees as a percentage of GDP, United States, 1960-2010 
decreased somewhat over the 2 or 3 decades preceding the crisis, the total share of household income in national income has actually remained rather stable.

In my view, these very powerful macroeconomic trends have a number of implications for economic theory. First, models focusing exclusively on the functional income distribution (as is the case in many post-Keynesian and other heterodox models) may miss an important part of the inequality-crisis nexus for the United States. ${ }^{2}$

Second, mainstream theories of consumption are unable to explain the decline in the household saving rate and the rise in household debt in the United States. In fact, the permanent income or life-cycle theories of consumption see no link between any given household's saving rate and its (permanent) relative income. Rather, some variants of these theories try to explain the decrease in the aggregate saving rate in the United States by referring to the socalled wealth effect. But the wealth effect cannot explain why the saving rate of the top 1 per cent, where most of the increase in wealth took place, has actually remained stable. Moreover, much of the increase in the net worth-to-income ratio of the bottom 95 per cent of the income distribution before the crisis was due to the rising prices of owner-occupied houses. Yet, as argued by Cynamon/Fazzari (2015a), in most cases an owner-occupied house merely signals an intention to consume future housing services. As few households actually decide to sell their house, an owner-occupied house should not generally be considered as an asset in which households park wealth that they intend to use later to pay down debt.

Third, the current renaissance of the long-neglected relative income hypothesis of consumption is in my view highly warranted.

\section{INCOME DISTRIBUTION AND MACROECONOMIC INSTABILITY IN GERMANY}

At first sight, the rise in inequality in Germany has been similar to that in the United States, at least when looking at the Gini coefficient of equivalized household disposable income, which is still the most routinely considered indicator of income inequality. However, when looking at top household income shares, no major shifts can be observed for Germany over recent decades, especially for the top 1 per cent household income share. This is also why, according to Piketty/Saez (2006), Germany can be qualified as an L-shaped country, whereas the United States and other Anglo Saxon countries have been qualified as U-shaped countries (cf. Figure 1).

It is problematic, however, to directly compare trends in top household income shares across countries without also looking at trends within the corporate sector, which is essentially owned by rich households. In Germany, the corporate sector has been a persistent net saver since 2002 (see Figure 4), due to a large extent to the rise in retained profits. Therefore, to the extent that retained corporate profits are not counted as household income, top household income shares à la Piketty may underestimate the rise of top-end inequality in Germany.

2. In particular, this casts some doubt on the suitability of the so-called 'Bhaduri-Marglin model' for empirical investigations into the 'wage-led' or 'profit-led' nature of economic growth in different countries. The original model by Bhaduri/Marglin (1990: 77, fn 1) assumes that the total income going to households (wages and distributed profits, if any) are consumed, and that a positive fraction of profits is saved. Given the stability of the share of total household income in the national income in the United States (Figure 3), it would seem difficult to argue that shifts to the distribution of income between the household and corporate sectors played a major role in affecting overall macroeconomic trends in the United States during the decades prior to the crisis of 2007. 


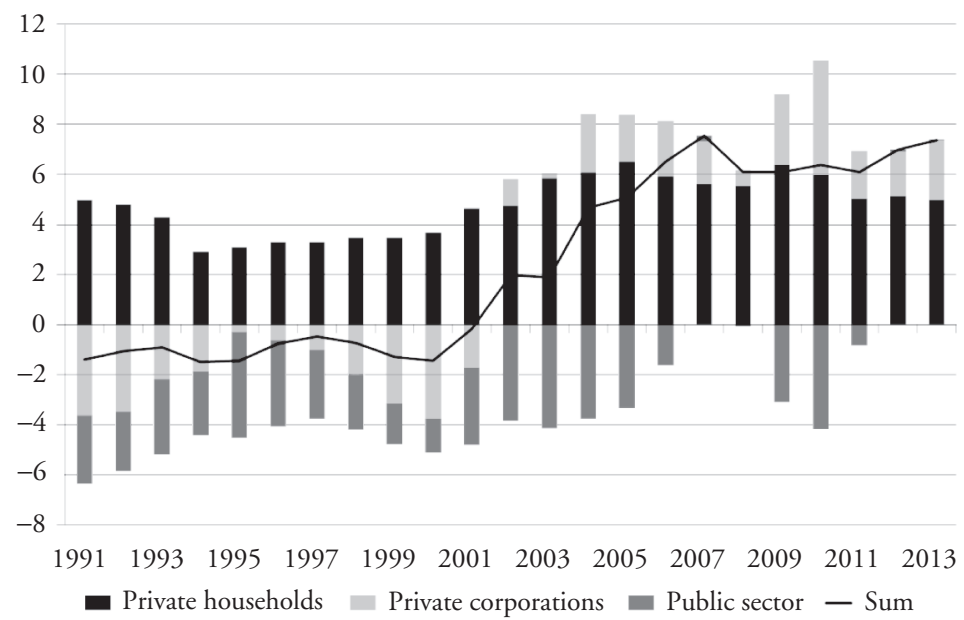

Source: Eurostat.

Figure 4 Sectoral financial balances as a percentage of GDP, Germany, 1991-2013

Figure 5 shows the rise in capital or profit income as a percentage of national income in Germany since the early 2000s, as well as the rise in corporate retained earnings as a share of disposable private income over the same period. Based on these trends, Figure 6 puts in perspective the development of top household income shares by taking into account the profits retained by corporations between 1995 and 2007.

Of course, it would be excessive to argue that all retained earnings should simply be counted as top household income. But Figure 6 can be thought of as a simple thought experiment, in that it shows what would have happened to personal income inequality if the German corporate sector had behaved more like the US corporate sector, which has passed rising returns on to top managers and shareholders, and thereby to the household sector.

The very different behaviour of German corporations is, of course, linked to the rather different institutional environment in Germany, where the shareholder value orientation of firms is much weaker compared to the United States, and where many firms are small and medium-sized enterprises which are often family-owned. Clearly, the main objective of many German firms does not seem to be to pay maximum salaries and dividends to their managements and shareholders, but rather to accumulate wealth within firms, in many cases with a view to passing this corporate wealth on to the next generation as inheritances.

In conclusion, it can be argued that the 'corporate veil' in Germany hides the true rise in inequality between households, when focusing only on measures of personal income distribution. But the rise in retained corporate profits also restrains domestic demand to the extent that the investment spending of firms has not increased proportionally to the rise in retained profits. Finally, and perhaps paradoxically, the rise in corporate saving has limited the pressure for the middle class to engage in debt-financed consumption, because rich households (which can be seen as the reference group for the middle class) have not increased their spending in proportion with the rise in incomes, but rather have increased their saving rate indirectly through corporate net saving. In this context, it should also be 
164 European Journal of Economics and Economic Policies: Intervention, Vol. 12 No. 2

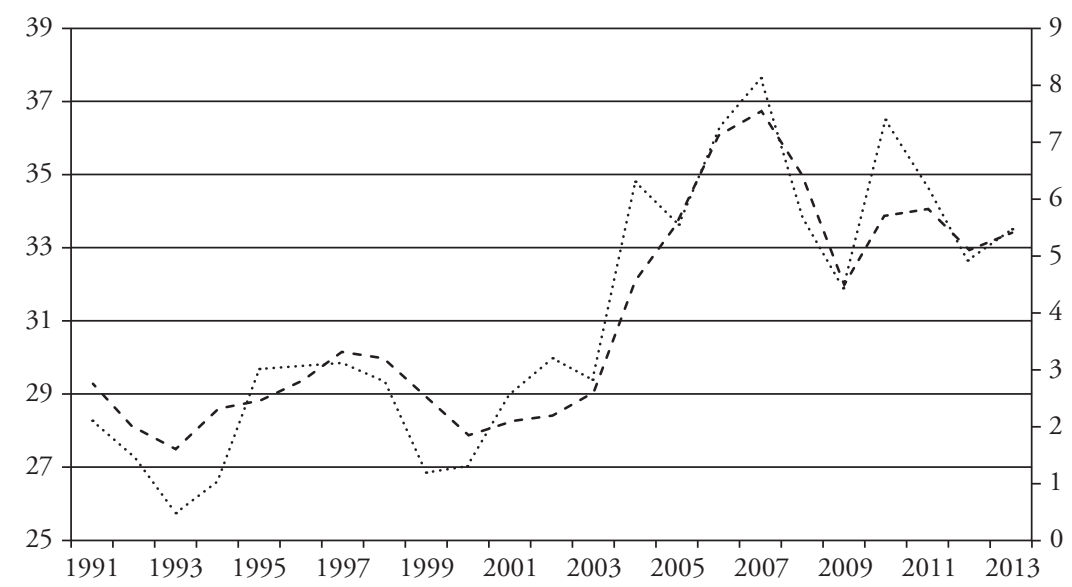

.. - Capital income as a percentage of national income (right axis)

.... Disposable corporate income as a percentage of disposable private income

Source: Statistisches Bundesamt.

Figure 5 Capital income and disposable corporate income, Germany, 1991-2013

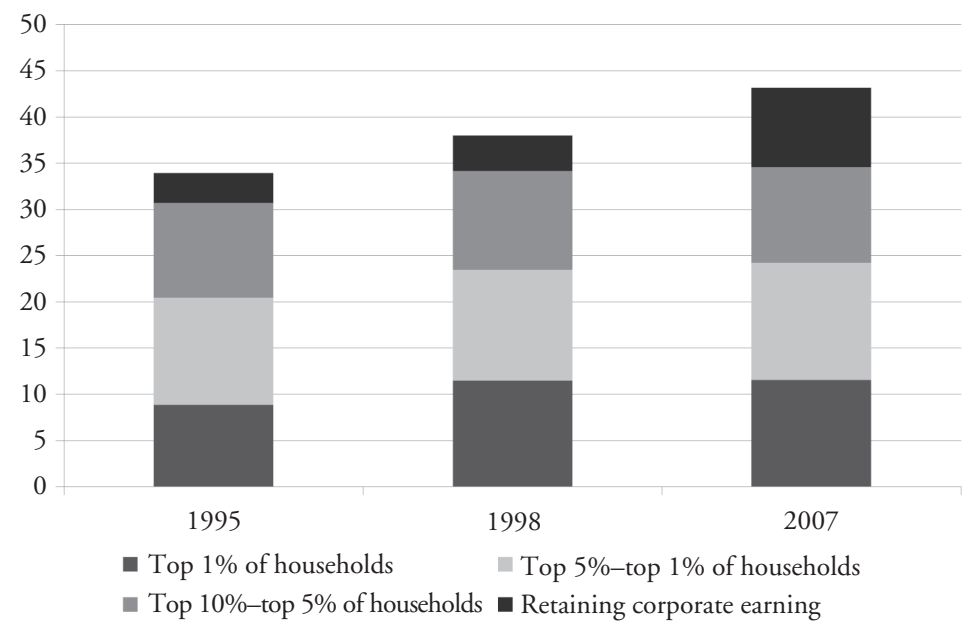

Source: Eurostat.

Figure 6 Top household incomes and retained corporate earnings as a percentage of private pre-tax income, Germany, 1995-2007

noted that the ability of the middle class in Germany to engage in debt-financed consumption is restricted in Germany by more conservative bank lending practices compared to the United States. Similarly, the much more extensive provision of public goods, compared to the United States, also limits the room for positional 'arms races'. 
Figure 4 places the financial balance of the German corporate sector in a broader macroeconomic context. As both the private household sector and the public sector have also been in or near financial surplus in recent years, the current-account surplus of the German economy has become structural. In sum, the weakness of domestic demand, caused in part by the shift in functional income distribution and corporate saving behaviour, has contributed to macroeconomic instability at the international level in terms of the global current-account imbalances.

Some observers (OECD 2010; 2012) have argued that the current-account surplus of Germany was due especially to weak investment spending, and they have concluded from this that Germany should deregulate its product and labour markets further, in order to give a boost to investment. However, the weak overall investment demand in Germany was due primarily to the weakness of public investment and construction investment, whereas business equipment investment, which in theory should be most sensitive to corporate profitability and regulations, has not been especially weak (van Treeck/Sturn 2012). Note also that net foreign direct investments account only for a small part of the rise in the corporate financial balance.

Koo (2015) argues that Germany was in balance-sheet recession at the beginning of the 2000 s, and that many corporations had to consolidate their balance sheets following the rise in corporate debt during the economic upswing and stock market boom of the late 1990s. However, the net flow of credit to the German corporate sector in the aggregate was negative for only 2 years, 2003 and 2004 (see also Koo 2015, figs 5.5 and 5.7). It is therefore questionable whether the concept of balance-sheet recession, whereby the corporate sector would 'minimize debt', actually applies for Germany for more than a short period of time. I would conclude that the main reason for the structural current-account surpluses and the weak domestic demand should be seen in the weakness of private household spending, caused in part by the shift in the functional distribution of income.

\section{FUNCTIONAL AND PERSONAL INCOME DISTRIBUTION AND CURRENT-ACCOUNT IMBALANCES}

The purpose of this section is to take a somewhat more systematic look at the relationship across countries between changes in top household income shares and the functional distribution of income on the one hand, and their implications for national current-account positions on the other. Figure 7 relates changes in top household income shares to changes in corporate financial balances as a percentage of gross domestic product (GDP) for the Group of Seven (G7) countries and China for the period of the mid 1980s to just before the crisis. Interestingly, top household income shares have increased most in those countries where the corporate financial balance has increased less (the United States and United Kingdom). A similar relationship exists for the change in top household income shares and the change in the share of wages in national income. In a sense, top management salaries and profits paid out to shareholders have stabilized wages and household income in the Anglo-Saxon countries, while in countries such as Germany, Japan and China, the rise in profits and corporate net savings is actually hiding the 'true' rise in income inequality.

Behringer/van Treeck (2013) estimated standard current-account equations on the basis of a macro panel including 20 countries for the period 1972-2007. The estimations include measures of the personal and functional income distribution as explanatory variables, while controlling for more standard determinants of current-account positions such as the initial net foreign asset position, the fiscal balance, relative per capita income, the old age dependency ratio, population growth and private credit. An important result is 


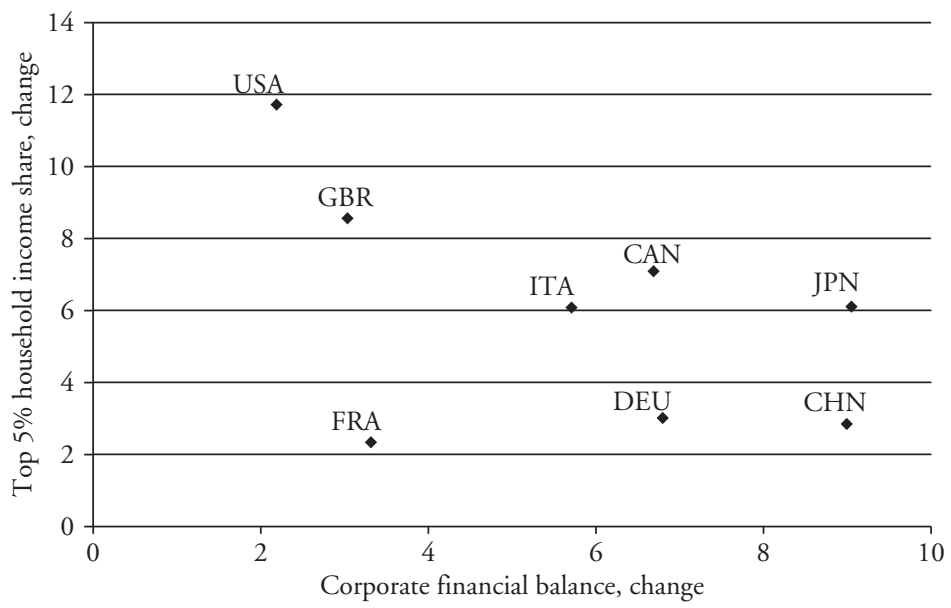

Note: The figure shows the change in, respectively, the corporate financial balance in per cent of GDP (horizontal axis) against the change in the top 5 per cent household income share (vertical axis). For the United Kingdom, changes are shown for the periods 1984/7-2003/7. For China changes are shown for the periods 1992/5-2000/3. For all other countries, changes are calculated for the period 1980/3-2004/7 or for the longest available time span within this period.

Source: World Top Incomes Database, Eurostat. See Behringer/van Treeck (2013).

Figure 7 Change in top household income shares against change in corporate financial balance as a percentage of GDP, G7 countries and China, mid 1980s to mid 2000s

that an increase in top income shares was linked to a decrease of the current account, while an increase in corporate net saving (or a decrease in the wage share) was linked to an increase of the current account. Also, taken together, the effects of changes in the personal and functional distribution could explain a considerable part of the current-account imbalances before the crisis.

As an overall conclusion, it can be argued that rising inequality generally tends to increase macroeconomic instability, but it depends crucially on the country-specific nature of inequality (as well as on country-specific institutions) whether instability materializes in the form of rising household indebtedness and current-account deficits, or in the form of weak domestic demand and excessive current-account surpluses.

\section{INCOME AND WEALTH INEQUALITY}

In his international bestseller Capital in the Twenty-First Century, Thomas Piketty (2014) has formulated a simple, but much-debated, model that can be used to analyse the link between income and wealth inequality. According to Piketty, the model consists of two 'fundamental laws of capitalism', even though the 'first law' is merely a definition, and the 'second law' is a simple arithmetic truism. ${ }^{3}$ More precisely, the first law defines the share of capital income in the national income, $\alpha$, as the rate of return on capital, $r$, times the wealth-to-income ratio, $\beta$. The 'second law' states that in long-term equilibrium

3. For an interesting critique of Piketty's interpretation of the model, see Bernardo et al. (2014). 
the wealth-to-income ratio, $\beta$, converges to the saving rate, $s$, divided by the nominal growth rate of the national income, $g$. Besides, Piketty argues that throughout the history of capitalism, there has been a tendency for the rate of return on capital, $r$, to exceed the growth rate, $g$. Piketty also shows that if the gap between $r$ and $g$ is large enough, then it can be expected that wealth will rise faster than income, and income and wealth inequality will rise indefinitely.

The crucial condition for the inequality $r>g$ to imply an indefinitely rising wealth and income inequality is that the saving rates of high-income groups significantly exceed the saving rates of lower-income groups, because if the saving rate were independent of relative income, $r>g$ would have no effect whatsoever on equilibrium income and wealth inequality, which would then be identical to wage inequality (that is, the traditional focus of attention in mainstream economics).

However, as we have seen above for the examples of the United States and Germany, the discrepancy between top-end and average saving rates has increased strongly in both countries, albeit in rather different ways: in the United States, lower-income groups have lowered their saving rates, presumably in an attempt to keep up with the spending patterns of the rich; whereas in Germany, rich households have increased their saving rates through corporate retained earnings. This means that, even independently of the precise relationship between $r$ and $g$, the increased gap between saving rates implies a tendency for the inequality of income and wealth to rise further.

While recent evidence documents the substantial rise in wealth inequality in recent decades for the United States (Saez/Zucman 2014), reliable data do not exist for Germany. The available data based on household surveys suggest that although income inequality has increased, wealth inequality has remained roughly stable since 2002 (Grabka/Westermeier, 2014). But these findings are called into question by the observations made above about recent trends in income distribution and saving rates in Germany (see also Behringer et al., 2014).

\section{INEQUALITY AND DEMAND STAGNATION}

In this short paper, I have argued that inequality was an important cause of the global financial crisis, which has materialized in some countries (for example, the United States) in the form of overindebted households, and in others (for example, Germany) in the form of excessive current-account surpluses which are linked to the overindebtedness of their trading partners. Clearly, this inequality-induced 'debt overhang' adds directly to the now much-debated risk of 'secular stagnation'.

Some economists argue that further structural reforms (that is, deregulation) in the product and labour markets are now needed to give a boost to investment. But a more fundamental question is how consumption demand, which after all makes up 60-70 per cent of GDP, can recover, given current levels of inequality and household debt. Generally speaking, for demand growth to recover in a sustainable way, middle- and lower-class incomes would have to move at least in parallel with average trend productivity. In fact, it would seem that some rather massive redistribution of income will be necessary to overcome the unsustainable debt-led and export-led models that we have seen before the crisis.

Economists should further improve their understanding of the links between the distribution of income and macroeconomic development. Because the nature and macroeconomic implications of rising inequality can vary substantially across countries, theoretical and empirical research should systematically include both the functional and the personal distribution of income. 


\section{REFERENCES}

Behringer, J., van Treeck, T. (2013): Income distribution and the current account: a sectoral perspective, Institute for New Economic Thinking (INET), INET Research Notes 35.

Behringer, J., Belabed, C., Theobald, T., van Treeck, T. (2013): Einkommensverteilung, Finanzialisierung und makroökonomische Ungleichgewichte, in: Vierteljahreshefte zur Wirtschaftsforschung - Nachhaltige Europäische Konsolidierungspolitik: Chancen und Herausforderungen, 82(4), 203-221.

Behringer, J., Theobald, T., van Treeck, T. (2014): Income and wealth distribution in Germany: a macro-economic perspective, Institut für Makroökonomie und Konjunkturforschung (IMK), IMK Report No 99.

Belabed, C., Theobald, T., van Treeck, T. (2013): Income distribution and current account imbalances, Institute for New Economic Thinking (INET), INET Research Notes 36.

Bernardo, J., Martinez, F., Stockhammer, E. (2014): A post-Keynesian response to Piketty's 'Fundamental Contradiction of Capitalism', Post Keynesian Economics Study Group Working Paper 1411.

Bhaduri, A., Marglin, S. (1990): Unemployment and the real wage: the economic basis for contesting political ideologies, in: Cambridge Journal of Economics, 14(4), 375-393.

Cingano, F. (2014): Trend in income inequality and its impact on economic growth, OECD Social, Employment and Migration Working Papers, No 163.

Cynamon, B., Fazzari, S. (2015a): Inequality, the Great Recession and slow recovery, in: Cambridge Journal of Economics, doi: $10.1093 / \mathrm{cje} / \mathrm{bev} 016$.

Cynamon, B., Fazzari, S. (2015b): Rising inequality and stagnation in the US economy, in: European Journal of Economics and Economic Policies: Intervention, 12(2), 170-182.

Dutt, A.K. (2006): Maturity, stagnation and consumer debt: a Steindlian approach, in: Metroeconomica, 57(3), 339-364.

Fitoussi, J.-P., Stiglitz, J.E. (2009): The ways out of the crisis and the building of a more cohesive world, Observatoire français des conjonctures économiques document de travail, 2009(17).

Frank, R.H. (2005): Positional externalities cause large and preventable welfare losses, in: American Economic Review, AEA Papers and Proceedings, 95(2), 137-141.

Frank, R.H. (2007), Falling Behind: How Rising Inequality Harms the Middle Class, Berkeley, CA: University of California Press.

Frank, R.H., Levine, A.S., Dijk, O. (2014): Expenditure cascades, in: Review of Behavioral Economics, $1(1-2), 55-73$.

Grabka, M., Westermeier, C. (2014): Anhaltend hohe Vermögensungleichheit in Deutschland, in: DIW Wochenbericht, 81(9), 151-164.

Hein, E., Truger, A. (2012): Finance-dominated capitalism in crisis: the case for a global Keynesian New Deal, in: Journal of Post Keynesian Economics, 35(2), 183-210.

Koo, R. (2015): Fighting balance sheet recessions: a Japanese lesson for the euro zone, in: Nowotny, E., Ritzberger-Grünwald, D., Schuberth, H. (eds), The Challenge of Economic Rebalancing in Europe: Perspectives for CESEE Countries, Cheltenham, UK and Northampton, MA: Edward Elgar (forthcoming).

Kumhof, M., Rancière, R. (2010): Inequality, leverage and crises, International Monetary Fund (IMF), Working Paper 10/268.

Kumhof, M., Lebarz, C., Rancière, R., Richter, A.W., Throckmorton, N.A. (2012): Income inequality and current account imbalances, International Monetary Fund (IMF), Working Paper 12/08.

Mian, A., Sufi, A. (2014): House of Debt: How They (and You) Caused the Great Recession, and How We Can Prevent It From Happening Again, Chicago, IL: University of Chicago Press.

OECD (2010): OECD Economic Surveys: Germany 2010, Paris: OECD Publishing.

OECD (2012): OECD Economic Surveys: Germany 2012, Paris: OECD Publishing.

Ostry, J.D. (2015): Inequality and the duration of growth, in: European Journal of Economics and Economic Policies: Intervention, 12(2), 147-157.

Ostry, J.D., Berg, A., Tsangarides, C.G. (2014), Redistribution, inequality, and growth, International Monetary Fund (IMF), IMF Staff Discussion Notes 14/02. 
Palley, T.I. (1994): Debt, aggregate demand, and the business cycle: an analysis in the spirit of Kaldor and Minsky, in: Journal of Post Keynesian Economics, 16(3), 371-390.

Palley, T.I. (2012): From Financial Crisis to Stagnation: The Destruction of Shared Prosperity and the Role of Economics, Cambridge, UK: Cambridge University Press.

Piketty, T. (2014): Capital in the Twenty-First Century, Cambridge, MA: Harvard University Press.

Piketty, T., Saez, E. (2006): The evolution of top incomes: a historical and international perspective, in: American Economic Review, 96(2), 200-205.

Rajan, R. (2010): Fault Lines: How Hidden Fractures still Threaten the World Economy, Princeton, NJ: Princeton University Press.

Saez, E., Zucman, G. (2014): Wealth inequality in the United States since 1918: evidence from capitalized income tax data, National Bureau of Economic Research (NBER), Working Paper 20625.

Stockhammer, E. (2013): Rising inequality as a cause of the present crisis, in: Cambridge Journal of Economics, 39(3), 935-958, doi: 10.1093/cje/bet052.

Van Treeck, T., Sturn, S. (2012): Income inequality as a cause of the Great Recession? A survey of current debates, International Labour Organization (ILO), Conditions of Work and Employment Series 39 . 